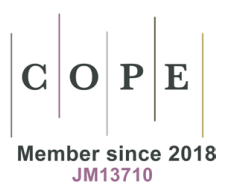

EUROPEAN SPATIAL RESEARCH AND POLICY

Volume 27 2020

Number 1

http://dx.doi.org/10.18778/1231-1952.27.1.12

\author{
Ksenia Yu. VOLOSHENKO* (D), Ivan S. GUMENYUK ${ }^{* *}$ (D) \\ Nils Göran ARNE ROOS $^{* * *}$ (D)
}

\title{
TRANSIT IN REGIONAL ECONOMIC DEVELOPMENT: THE CASE OF THE KALININGRAD EXCLAVE
}

\begin{abstract}
The study analyses the role of the transit function in the development of a regional transport system drawing on the example of the Kaliningrad exclave region (Russia). The article studies the role and extent of the impact of changes in the volume and structure of transit operations on the value-added creation in the regional economy. The assessment of the transit function was conducted using analytical software for strategizing and situational forecasting of the socio-economic development of the Kaliningrad region, the analogue of which is the CGE-model. The article describes the results of the regional value-added modelling based on the integrated index of gross regional product (GRP) and the changing volume and structure of transit cargo. The article explores the transit specialisation options for the Kaliningrad region based on different scenarios of its social and economic development and the changes in external factors. The results can be applied to similar studies on assessing the transit potential of a particular territory and developing measures to support the transportation system development in other regions.
\end{abstract}

Key words: transit, transportation system, regional economy, situational forecasting and strategizing, Kaliningrad region.

\footnotetext{
* Ksenia Yu. VOLOSHENKO, Immanuel Kant Baltic Federal University, Centre for Regional Socio-Economic Development Modelling, Kaliningrad, Russia, e-mail: KVoloshenko@kantiana.ru, ORCID: https://orcid.org/0000-0002-2624-0155

** Ivan S. GUMENYUK, Immanuel Kant Baltic Federal University, Department of Geography, Nature Management, and Spatial Development, Kaliningrad, Russia, e-mail: IGumeniuk@kantiana. ru, ORCID: http://orcid.org/0000-0002-8477-5342

*** Nils Göran ARNE ROOS, Flinders University, Australian Industrial Transformation Institute, Adelaide, Australia; Baltic Federal University, Institute of Economics and Management of the Immanuel Kant Baltic Federal University, Kaliningrad, Russia, e-mail: goran@roos.org.uk, ORCID: https://orcid.org/0000-0003-0943-3585
} 


\section{INTRODUCTION}

The growing geopolitical and economic turbulence increases the importance of economic enhancement through the utilisation of the territorial potential for any region, including Russian ones (Anokhin and Fedorov, 2018). Transportation is one of the sectors with a significant potential for the transformation of a regional economic development model, as shown by a retrospective analysis (Macheret and Epishkin, 2017) and numerous empirical and theoretical studies (Wang et al., 2018). Furthermore, the importance of transportation for a transit territory increases both as it provides growing regional accessibility, investment and trade opportunities and its active involvement in cross-border processes that opens the possibility of its further integration into cross-border functional (transport) territorial systems (Gumenyuk and Melnik, 2013).

In order to study the role of the transit function in the development of the transport system and regional economy, the article considers the case of the Kaliningrad region. The economic prospects of the transport system of the Russian exclave are primarily associated with its specialisation in transit. The choice of this region as a research object is not trivial. On the one hand, being an exclave territory, the Kaliningrad region is a unique object for regional studies since it is very close to the idealised concept of the region. On the other hand, there are very few economically interesting regions of this type in the world. This puts them into the category of phenomena rather than makes them the research objects requiring close attention (Gareev and Voloshenko, 2015). There is a number of other objective reasons for selecting the Kaliningrad region as a territory for the examination of the transit function. The first one is its geographical location. It has access to the Baltic Sea and through it to the World Ocean. The region is located on the path of global transport corridors that historically played a fundamental role in the development of the Eurasian continent (the route 'from the Varangians to the Greeks', 'The Amber Road', 'The Great Silk Road') and are still actively developing within the "One Belt, One Road" global geopolitical project (Druzhinin and Dong, 2018). Secondly, it is the opportunities for opening the transit in the Kaliningrad region by dint of the existence of several modes of transport and unique infrastructural advantages. For example, it has two types of railway track gauges - Russian (1,520 mm wide) and European $(1,435 \mathrm{~mm})$. Thirdly, transit is an important part of the development strategy of the transport system as a sector of the regional economy. The small size of the territory, as well as the limited domestic production and resource potentials, compromises the development of domestic freight transportation, and causes the modest volume of external goods consumed by the regional economy and of goods produced for international or interregional export. In this setting, the transit function becomes essential for the regional transport system development 
and its integration into global supply chains (Rutner and Langley, 2000) aimed to increase the regional value-added and economic growth in related sectors and industries.

Contemporary literature discusses transit and in-transit cargo transportation development and support through several lenses. Firstly, it studies it from the standpoint of international trade promotion, simplification of procedures, as well as the implementation of national initiatives, international transit agreements, transport and trade corridors projects (see, e.g. Kunaka and Carruthers, 2014; Button and Button, 2005). Secondly, it views it from the perspective of existing administrative, institutional, infrastructural, technical, informational, and other barriers to the cross-border movement of goods and service ("Protocol amending the Marrakesh agreement establishing The World Trade Organization, decision of 27 November 2014", 2014) which affect trade and transportation costs (e.g. Bernhofen et al., 2016). Thirdly, it studies the impact of supply chain uncertainty and demand uncertainty (Khan and Thomas, 2007) on trade, and, to a lesser extent, the features of value-added generation (Lam, 2012). The key categories are 'time' (Hummels and Schaur, 2013) and 'costs'. They are the most important performance indicators of any transit process for investors, traders, and businessmen (Hansen and Annovazzi-Jakab, 2008). Apparently, there are only a few publications on transit measurement including both case studies and theoretical issues of the value creation. These studies are mainly carried out within the conceptual framework of logistics and supply chain management (e.g. Rodrigue, 2012), as well as the participation of countries, clusters, sectors, and industries in global value chains (Morrison et al., 2008). Researchers primarily focus on the impact of transit on the economies of individual countries, especially of those in the Baltic Sea region (Litvinenko and Palšaitis, 2006; Bulis and Škapars, 2013).

The purpose of this study is to explore the role and influence of the transit function on the additional value creation in the regional economy. The study models the impact of changing in-transit cargo structure and growing involvement of the regional enterprises in the supply chains (cargo carriage services, storage, customs clearance, insurance, etc.) on the added value. The calculations are carried out using the regional analytical software for strategizing, and situational forecasting of the socio-economic development of the Kaliningrad region ${ }^{1}$. Based on the calculations results, the article proposes a package of policy measures facilitating the attraction of high-paying freight to promote the development of transport as an effective sector of the economy.

\footnotetext{
${ }^{1}$ Certificate of state registration of the computer program No. 2016617454 of 6 July 2016.
} 


\section{THEORETICAL BACKGROUND. TRANSPORT STUDY MODELS AND TRANSIT ASSESSMENT}

There is a large number of different classes of models used to study transportation (Chow et al., 2010): direct facility flow factoring method; O/D factoring method; truck model; four-step commodity model; economic activity model and their varieties. Tavasszy (Tavasszy, 2006) provided an overview of their different types in the three priority areas of freight modelling: freight - economy linkages (the most commonly used is the spatial computable general equilibrium (SCGE) model), the logistics behaviour (using origin/destination (O/D) tables) and networks (the most commonly used is multimodal network assignment for freight). They include trip generation models, I/O; synthetic $\mathrm{O} / \mathrm{D}$ models; gravity models; logistics choice models; multimodal networks; agent-based simulation models; land use - transport interaction (LUTI) models and computable general equilibrium (SCGE) models; network assignment and simulation, etc. They are mainly used for addressing the freight modelling and freight forecasting tasks aimed at ensuring transport accessibility and/or reducing transport costs in a particular country, region, city (e.g. freight-flow models and related logistics costs models). The algorithm of each of the known groups of models, ultimately, tackles the issue of freight demand and supply compatibility. The most common spatial interaction models include gravity models, entropy models, and intervening opportunities models.

A special role in the assessment of transit and economic efficiency belongs to Data Envelopment Analysis models and their modifications (CCR, BCC, FDH models, windows model, etc.). Researchers mainly focus on the analysis of the transit efficiency of public and private transport (Chiu et al., 2011). For example, some papers analyse the operational performance of air transport and airline networks (Barros and Peypoch, 2009), and the transit efficiency of international ports and port infrastructure (Brooks and Cullinane, 2007).

Havenga (2018), Tavasszy and De Jong (2013) have noted that the analytical applications of most modern transport models have some disadvantages and limitations. In particular, they do not take into account transportation and logistics as the elements of macroeconomics and public policy. Neither do they link them with other elements of the supply chain or take into account the behavioural and decision-making foundations of actors. Also, the models do not enable one to measure the impact that the achieved results and changes in the industry (infrastructure development, capacity growth, etc.) have on the economic growth and related socio-economic indicators. Researchers pay special attention to model deficiencies (Chow et al., 2010) in terms of assessing transit and transboundary effects, as well as trade corridors and border planning. The added value in transport chains is discussed mainly within the framework of Supply Chain Management (SCM) (Chen and Notteboom, 2014). 
There are several issues requiring proper consideration in studying the impact of the transit function on the value-added generation in the region. Firstly, it is the ongoing integration of transport chains into production systems with freight transport offering a full range of services that meet cost, time and reliability requirements, and, therefore, playing an increasingly important role in value chains. Here, the geography of value chains is integrated into the geography of transport systems (Rodrigue, 2017). Secondly, given the U-shaped curve (the 'smiling curve') (Ye et al., 2012) of the value chain profitability, it is the highest at the beginning and the end (logistics, sales, after-sales service) (Dementiev et al., 2018). This supports the argument for focusing on high-paying freight and final products transportation in order to increase the added value in the regional transport system. Thirdly, the increase in the added value of the regional transport system implies the search for an optimum ratio between the elements involved in its generation.

The issue of the redistribution of added value in favour of regional companies and organisations requires an independent study using sectoral simulation models developed by the authors of the article (Voloshenko and Ponomarev, 2018). There is a series of publications on the research results being prepared. The applied simulation models provide the opportunity to assess the impact of various regulatory and controlling factors on the added value in different sectors, industries and the economy of a region as a whole. The authors' models, including the ones for the transport system, were developed and tested using the data of the Kaliningrad region in 2014-2016. The application of the author's simulation model to the transport system of the Russian exclave enables one to assess the effect that an increase in freight turnover and the number of operations in the transport services provided has on the added value.

\section{ADDED VALUE MODELLING AND THE TRANSIT POTENTIAL THE DATA AND THE METHODOLOGY}

The assessment of the region's transit trade intensity and its effect on the value-added generation requires a comprehensive solution to several research tasks. These include: a) the modelling of the influence of transit parameters on additional value-added generation in the region; b) the development of the mechanisms and the selection of measures and projects promoting regional transit trade aimed at the subsequent growth of value-added in the industry; c) the identification of conditions for increasing added value by changing the volume and structure of transit cargo, redistributing added value and chains in favour of regional companies and organisations. 
The study tackles the first task and partly the second one. Using the example of the Kaliningrad region and based on the calculations results, it outlines proposals and provides forecast estimates for changes in the regional transit specialisation aimed at additional value-added generation. To select measures and projects promoting regional transit trade in order to ensure the subsequent growth of added value, the authors applied scenario planning. The scenarios consider the probabilistic general changes in the regional socio-economic development, including the implementation of investment transport projects, as well as external geopolitical and geo-economic factors. The scenarios also considered the global economic and infrastructure development trends directly affecting the region's transit trade potential. Ultimately, the formulated proposals aim at increasing transit function of the Kaliningrad region's transport system.

Given the analytical limitations of the existing transport models, it is appropriate to use regional forecast models incorporating transport and logistics as part of the regional economy. Gareev and Voloshenko (2015) in their work examined the advantages and disadvantages of various tools and technologies for forecasting and modelling. For this reason, the simulation of the transit parameters influences on the regional added value is conducted using the regional analytical software for strategizing and situational forecasting of the Kaliningrad region development. This software is based on the 'Region', the RF subject's socio-economic activity model, designed by Prof V.A. Tsybatov (SSUE, Samara) (Tsybatov, 2017). The model has been developed within a class of models regarding economic development as a result of its economic agents' - the main subjects of socio-economic processes - activity. The prototypes of the developed model are Computable general equilibrium models (CGE).

Let us briefly consider the methodological features of the model construction. Agent-based models are presented as control systems based on deviations. Ambition determines the behaviour of each economic agent, as in order to achieve a particular outcome (target) an agent shall follow a particular behaviour (path). An agent monitors the current deviation from the target and generates control actions on its bidirectional generalised production function (GPF) taking into account its environment (market conditions and resource status) and external (scenario) management.

The description of economic agent-based models includes the description of its assets, GPF, and patterns of behaviour within the reproduction process. The economic agent's assets include fixed capital, productive capacity, available funds (cash and bank balances), and the current stocks of intermediate and finished products. The agent's bidirectional GPF, on the one hand, shapes its offer in respective markets and, on the other hand, it generates a demand for intermediate products and production factors in accordance with the agent's technological matrix. Agent-based modelling is a solution to a multi-criteria optimisation problem. This is the problem of finding the optimal control minimising the general frustra- 
tion associated with the goals not being achieved by a certain point in the forecast period considering external (scenario) management and resource constraints. Modelling offers a simultaneous solution of interrelated multi-objective tasks for all economic agents.

The generalised economic agents' target indicator vector can be defined as:

$$
E(t)=\left[e_{1}, e_{2}, \ldots, e_{m}\right]^{T},
$$

The target vector expression for these indicators can be defined as:

$$
E^{0}(t)=\left[e_{1}^{0}, e_{2}^{0}, \ldots, e_{m}^{0}\right]^{T}
$$

The control vectors of economic agents are combined into a generalised control vector:

$$
U(t)=\left[U_{1}(t), U_{2}(t), \ldots, U_{N}(t)\right]^{T}=\left[u_{1}(t), u_{2}(t), \ldots, u_{N}(t)\right]^{T},
$$

Then, the combined multi-criteria task for all economic agents can be defined as follows:

$$
\min _{U \subset D_{U}}\left\{\sum_{i=1}^{m}\left\{g_{i} \sum_{k=1}^{T}\left|\frac{e_{i}\left(U, U^{\text {exe }}, t_{k}\right.}{e_{i}^{0}\left(t_{k}\right)}\right|\right\}\right\}
$$

Where $e_{i}\left(U, t_{k}\right)$ is the solution to the $i$-th local optimisation problem $(i \in[1,2, \ldots, m])$ at the point $t_{k} \in\left[t_{1}, t_{2}, \ldots, t_{T}\right]$ that is solved by the corresponding economic agent within its resource constraints; $U^{\text {exe }}(t)$ - the vector of scenario parameters specified by a researcher at the points $t=t_{1}, t_{2}, \ldots, t_{T}$ in a forecast period (exogenous scenario); $g_{j, i}$ - significance (weight) of the $i$-th target indicator. A researcher sets the control solution space $D_{U}$ by setting the control intervals for the generalised control vector elements $U(t)$.

With $\mathrm{U}^{(0)}$ being the initial approximation of the control matrix $\mathrm{U}$ (baseline scenario), the control matrix $U$ takes the following form:

$$
\mathrm{U}=\mathrm{U}^{(0)} \otimes K .
$$

Where $K=\left\|k_{i, j}\right\|_{n \times T}$ is a correcting matrix of $n \times T$ dimension;

Where $\otimes$ is the symbol of the element-wise multiplication of matrices.

The correcting matrix, in turn, is the element-wise product of local correcting matrices compiled for local optimization tasks by the number of target indicators:

$$
K=K_{1} \otimes K_{2} \otimes \ldots \otimes K_{m}
$$


Formula (5) enables one to reduce the problem (4) to the search for the optimal correcting matrix $K^{\text {opt }}$. V.A. Tsybatov (2017) has developed an effective method for finding the optimal matrix $K^{\text {opt }}$, which enables one to solve class (4) problems or many dozens of local goals $m$ and hundreds of control variables $n$ within a reasonable amount of time. Designed on the basis of the matrix method, this solver automatically builds the optimal control matrix:

$$
\mathrm{U}^{(0)} \otimes K^{o p t} \rightarrow \mathrm{U}^{\mathrm{opt}}
$$

for which the values of target indicators (1) are as close as possible to the set targets (2), considering the significance of these indicators ( $g_{i}$ weights) and the restrictions on $D_{U}$ control actions.

The model's database sources include publicly available regional statistics, reports of regional ministries, and departments of the subjects of the Russian Federation.

In this research, the model has been applied for situational forecasting. Its results form the basis for the assessment of the changes in macroeconomic indicators under several transit intensification scenarios, including the changes in the freight turnover structure with the prevalence of intermediate, capital or consumer goods. The scenario comparison enables the identification of the best transit development path aimed at the generation of additional added value in the Kaliningrad region considering external constraints. It also makes it possible to propose institutional and economic measures to support its development.

\section{THE RESULTS. TRANSIT MODELLING IN THE REGIONAL ECONOMY}

\subsection{Transit and freight turnover in the Kaliningrad region}

The analysis of the dynamics of freight turnover in the Kaliningrad region (Fig. 1) indicates that in the period from 2003 to 2014 the transit trade volume in the Kaliningrad region increased in response to the growth of the total freight turnover. This was facilitated by favourable macroeconomic and institutional conditions, most of all, by the Special Economic Zone regime in the region. There have been several major investment projects implemented in the region resulting in a significant increase in the commodity flows (international and interregional import/ export). However, the global crisis and the unfavourable trading environment in the region (to a large extent associated with the introduction of EU and US sanctions on Russia and its countermeasures) led to a dramatic decrease in both freight turnover and transit in subsequent years. It was only 2017 that saw the beginning of an emerging upward trend. 


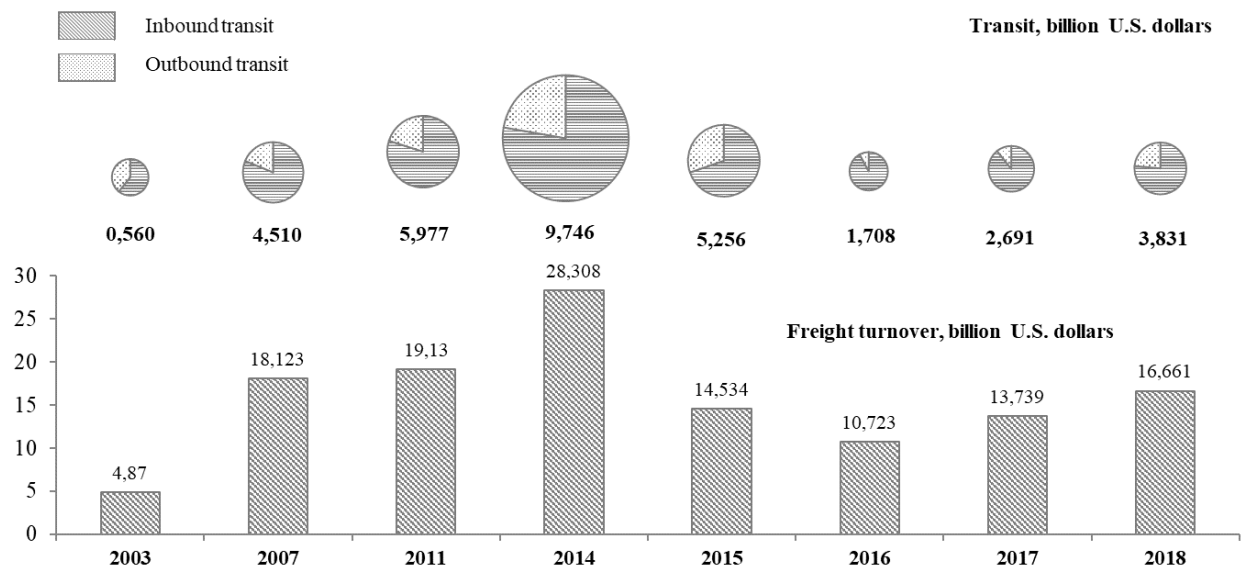

Fig. 1. Dynamics of freight turnover and transit in the Kaliningrad region, 2003-2018

Source: own work based on the data of the Kaliningradstat, Kaliningrad Regional Customs Office made with the "Situational Forecasting and Strategizing of the Socio-Economic Development of the Kaliningrad Region" analytical software (hereinafter the IKBFU AS).

The estimated values for 2014-2018 show the following trends in the structure of the freight turnover and transit in the Kaliningrad region (see Table 1):

- the most common export goods and services (excluding transit) were consumer ones, mainly because of the volume of their export to the regions of the Russian Federation, while the most common international exports were intermediate goods and services;

- at the same time, the most common imports on both international and interregional levels (excluding transit) were intermediate goods and services;

- the most common transit goods and services were intermediate and capital ones, because of their large share in the international imports.

The unfavourable geopolitical situation, the deterioration of the economic situation, accompanied by the fall in the regional production, as well as domestic consumption, led to a sharp drop of 50\% in freight turnover in 2015 compared to 2014 (Fig. 2). In turn, the prime cause for a further decline in freight turnover by $26.1 \%$ in 2016 was the reduction in transit operations and the decreasing import of consumer goods and services caused by the sanctions and the low real disposable income. At the same time, a minor revival of production in the region led to a slight increase (by 3.7\%) in the import of intermediate goods and services. Thus, the reduction in freight turnover in 2016 was caused by a significant drop in transit (from 5.2 to 1.7 billion USD), while the regional consumption has declined only by $3.2 \%$ (from 9.3 to 9.0 billion USD). In 2017-2018, growth in freight traffic was caused mainly by the growth in regional consumption. 
Table 1. Structure of import, export and transit (percentage)

\begin{tabular}{|l|c|c|c|c|c|c|c|c|c|}
\hline \multirow{2}{*}{ Name } & \multicolumn{3}{|c|}{$\mathbf{2 0 1 4}$} & \multicolumn{3}{c|}{$\mathbf{2 0 1 6}$} & \multicolumn{3}{c|}{$\mathbf{2 0 1 8}$} \\
\cline { 2 - 10 } & $\mathbf{i}$ & $\mathbf{k}$ & $\mathbf{c}$ & $\mathbf{i}$ & $\mathbf{k}$ & $\mathbf{c}$ & $\mathbf{i}$ & $\mathbf{k}$ & $\mathbf{c}$ \\
\hline Export (excluding transit) - total & 11.7 & 4.2 & 84.1 & 21.3 & 4.9 & 73.8 & 10.6 & 5.0 & 84.3 \\
\hline interregional export & 3.0 & 4.4 & 92.6 & 2.3 & 5.6 & 92.1 & 4.8 & 5.3 & 89.9 \\
\hline international export & 57.4 & 3.4 & 39.2 & 73.4 & 3.2 & 23.4 & 40.7 & 3.8 & 55.4 \\
\hline Import (excluding transit) - total & 71.0 & 8.5 & 20.6 & 78.4 & 3.7 & 17.9 & 79.1 & 4.4 & 16.5 \\
\hline interregional import & 63.0 & 2.0 & 35.1 & 54.8 & 10.0 & 35.2 & 56.0 & 6.9 & 37.0 \\
\hline international import & 72.3 & 9.6 & 18.0 & 82.0 & 2.7 & 15.3 & 82.5 & 4.0 & 13.5 \\
\hline Transit - total & 69.6 & 23.2 & 7.2 & 69.7 & 14.2 & 16.1 & 58.4 & 25.2 & 16.5 \\
\hline $\begin{array}{l}\text { International imports to the RF } \\
\text { through the region }\end{array}$ & 71.4 & 22.1 & 6.5 & 70.9 & 15.4 & 13.7 & 70.2 & 8.3 & 21.5 \\
\hline $\begin{array}{l}\text { International exports from the } \\
\text { RF through the region }\end{array}$ & 60.5 & 29.1 & 10.4 & 56.1 & 0.0 & 43.9 & 54.7 & 30.3 & 14.9 \\
\hline
\end{tabular}

Note: $\mathrm{m}$ - intermediate goods and services, $\mathrm{k}$ - capital goods and services, $\mathrm{c}$ - consumer goods and services

Source: own work based on the data from the Kaliningradstat, the Kaliningrad Regional Customs made with the IKBFU AS

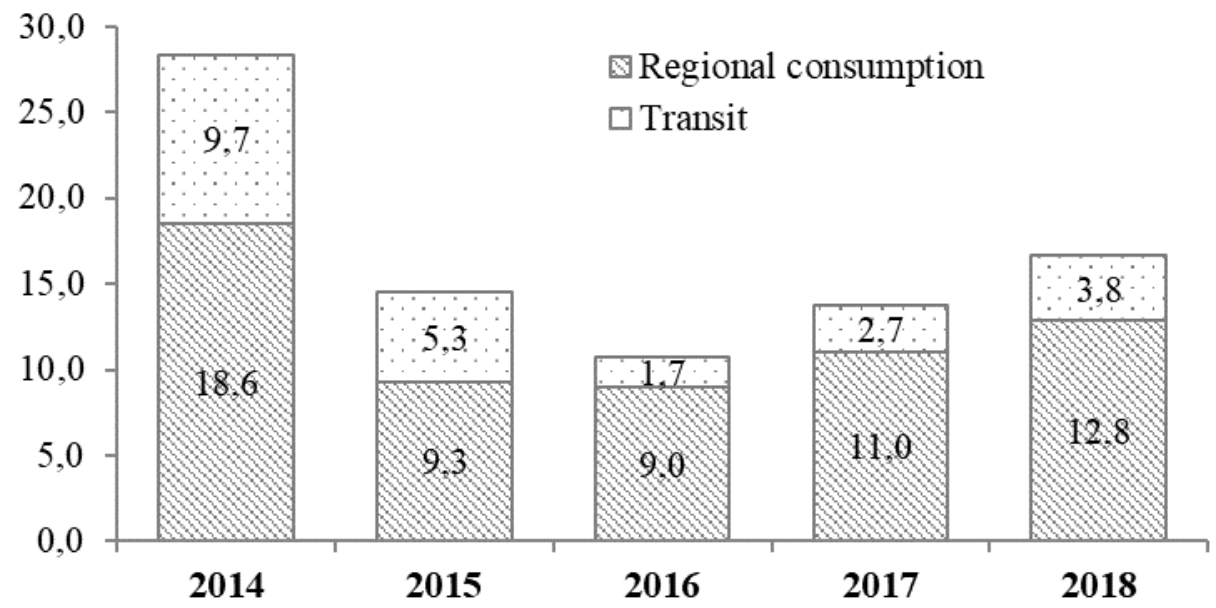

Fig. 2. Comparative assessment of freight turnover in regional consumption and transit of the Kaliningrad region, billion USD

Source: own work based on the data from the Kaliningradstat, the Kaliningrad Regional Customs made with the IKBFU AS. 
The total freight turnover was 13.7 and 16.7 billion USD in 2017 and 2018, respectively. The doubling of transit trade in recent years has been the result of the resumption of mineral products import-export traffic in the region.

The analysis of transit indicators shows its profound significance for and considerable impact on the general freight turnover in the Kaliningrad region. The prospects for further transport system development and the growth of the regional economy are directly linked to the change in the structure and volume of transit freight handled.

\subsection{Results of transit freight forecast modelling}

Despite the decrease in the share of transit cargo in the region in previous years, it is realistic to expect increasing use of its transit potential. The following factors will be the main drivers of this process:

- closer integration of two transcontinental initiatives - the Eurasian Economic Union (EAEU) and 'One Belt - One Way';

- the joint initiative of Russia and China aimed at strengthening the interconnectedness in the domains of logistics, transport infrastructure, and intermodal transport;

- prospects for the implementation of major infrastructure projects: the international transport route 'Europe - Western China' passing through Kazakhstan, Russia, Belarus; the Moscow - Beijing high-speed rail; 'Primorye-1' and 'Primorye-2' transport corridors, and more;

- the joint program of Russia, China and Mongolia to build an economic corridor involving the development of transport infrastructure as well as the construction of checkpoints and control points;

- the possibility of creating a free trade zone between Iran and the EEU with one of its infrastructural elements being the International North-South Transport Corridor linking Iran with Northern Europe.

In the short term, the most significant factor in the development of transit capacity of the Kaliningrad region will probably be the active participation of the region in the implementation of the 'One Belt, One Road' initiative. Within its framework, the region is considering the idea of implementing a logistics project of a dry port for the transhipment and storage of goods on 300 hectares in Chernyakhovsk industrial park.

To measure the impact that the transit structure has on the economy of the Kaliningrad region, the study examined three possible scenarios. The benchmark for comparison were the forecast parameters of the socio-economic development of the Kaliningrad region in 2019-2035 developed and approved by the Ministry of Economy of the Kaliningrad Region. The research considered the influence of geopolitical factors, the potential capacity of the regional transportation system, and the possible changes in the freight structure based on the geography of suppliers. 
Baseline conditions: the socio-economic development of the Kaliningrad region for the period until 2035 is characterised by gradually increasing growth rates of the key sectors of the regional economy (industry, agriculture, trade, and services) and a moderate increase in labour productivity.

Conservative scenario (1). It is based on an increase in the utilisation of the existing transport system capacity and the focus of transit trade on the transportation of intermediate goods $(\mathrm{m})$. The region will specialise in servicing domestic industries located in other regions of Russia, as well as it will ensure the export deliveries of Russian raw materials.

Integration scenario (2). This scenario entails the Kaliningrad region playing an active part in global transport corridors with the associated growth of processed consumer goods volume (c) on the APR-EU route.

Target scenario (3). This scenario entails a balanced development of the transport system of the Kaliningrad region including the utilisation of the existing transport and transit potential both nationally and internationally. This implies an increase in the share of capital (k) and consumer (c) goods and services handled in transit with intermediate goods and services $(\mathrm{m})$ retaining a significant share in its structure.

The results of the calculations made using the IKBFU AS show a $25-30 \%$ growth of goods and services in foreign trade operations (intermediate ones in scenario 1 , consumer ones in scenario 2, capital ones in scenario 3 ) comparing to the benchmark, ceteris paribus.

Fig. 3 shows the results of the modelling changes in transit and in the Kaliningrad region's GRP in 2019-2035.

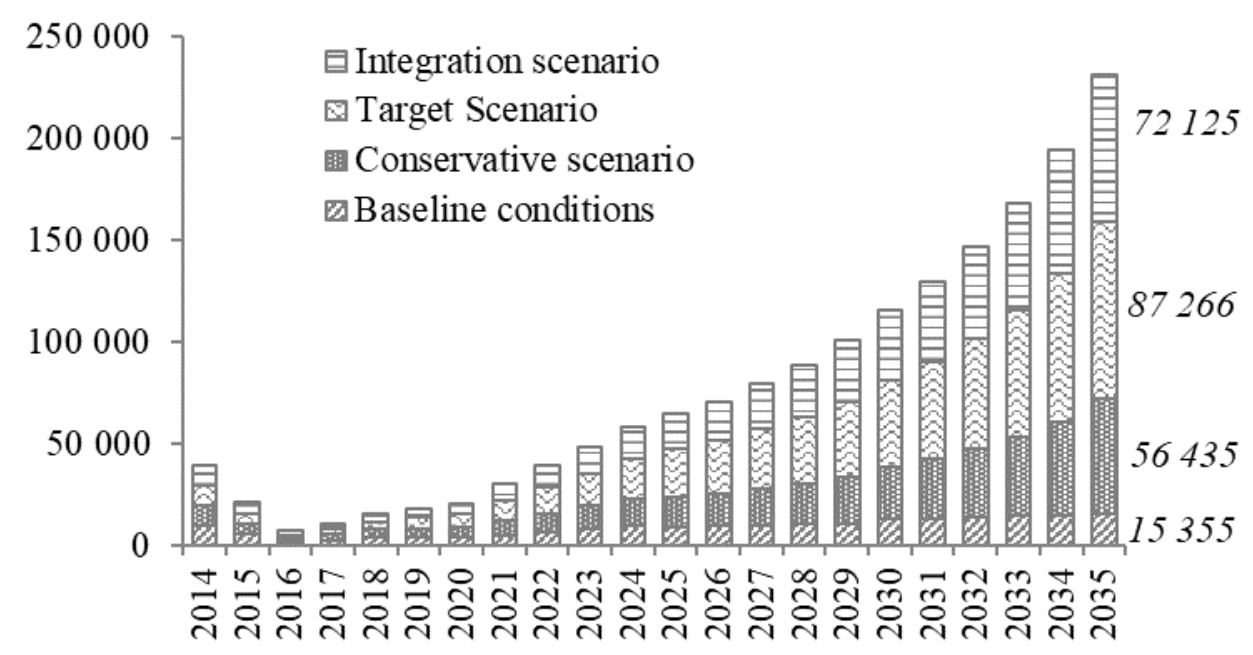

Fig. 3. Transit dynamics in the Kaliningrad region, millions USD Source: IKBFU AS calculations. 
Under the baseline conditions, the GRP is to increase by a factor of 1.56 by 2035 compared to 2014. However, the development of transit specialisation in the region will lead to its increase by $21.3 \%$ if it focuses on capital and consumer goods and services (Target Scenario), by $14.3 \%$ if it focuses on consumer and intermediate goods and services (Integration scenario), and by $9.6 \%$ if the prevailing goods and services will be intermediate ones (Conservative scenario). The largest increase in transit volumes is observed under the target scenario, it is a 5.7fold increase comparing to the baseline conditions.

Accordingly, the increase in added value, as well as in transit volumes, is associated with a significant share of capital and consumer goods and services in the freight structure (Fig. 4) accompanied by the increase in the share of transit in the freight turnover in the region.

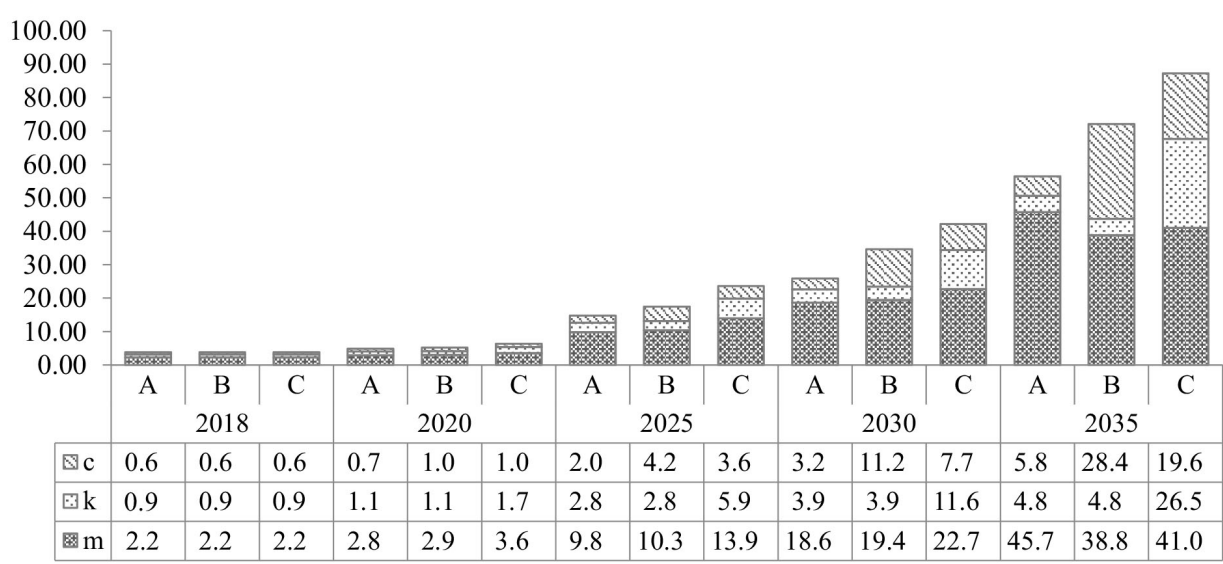

Note: A - Conservative scenario, B - Integration scenario, C - Target scenario; $\mathrm{m}$ - intermediate goods and services, $\mathrm{k}$ - capital goods and services, $\mathrm{c}-$ consumer goods and services Fig. 4. Forecast for the volume and commodity composition of transit trade in the Kaliningrad region until 2035

Source: IKBFU AS calculations.

By 2035, under the Integration and Target scenarios, the share of transit will be more than $70 \%$ of the total freight turnover. Scenario calculations allow us to establish the dependence of the added value on the transit trade in the Kaliningrad region. For example, with the doubling of transit volume, there is an additional added value in the range of $5.8 \%$ if the increase is in capital goods and services, $5.0 \%$ if it is in consumer ones, and $4.6 \%$ if it is in intermediate ones. Thus in order to achieve the greatest impact on the regional economy, it is important to increase in-transit capital and consumer goods and services. 


\subsection{The development of specialisation in transit}

The results of the analysis along with the assessment of the forecast parameters of the economy and the transport system development in the Kaliningrad region enabled us to formulate final proposals. Their implementation shall stimulate the development of transit specialisation of the region.

1. The integration of the Kaliningrad region into international transport corridors through the creation and development of a technically and technologically integrated transport and logistics infrastructure, as well as supply chain management systems. Special attention should be applied to the development of end-toend services along transport corridors, involving an optimum interaction between all participants in the goods supply process including customs and border services.

2. The creation of institutional and economic conditions enhancing the participation of Kaliningrad transport organisations in the carriage of Russian export and import cargo. It is essential to use the federal support to ensure that Kaliningrad's transport companies work based on the same conditions as other carriers do. This shall cover the issues of tariff policy of neighbouring countries, as well as customs procedures.

3. The consideration of the problems of the Kaliningrad region and the interests within the framework of international integration projects and initiatives. This applies to the agreements reached within the framework of the Common Economic Space, as well as the Commonwealth of Independent States, the Shanghai Cooperation Organization, and the Asia-Pacific Economic Cooperation. It is important for the Kaliningrad region mainly in terms of its possible participation in such projects as 'One Belt, One Road' and Asia-Pacific transport corridors projects.

4. The development of a comprehensive program for the utilisation of the transit potential of the Kaliningrad region. It is advisable for all stakeholders to ensure the elaboration of specific strategic and program measures at the regional level aimed at the development of the transit capabilities of the Kaliningrad region. It is important to ensure the collaborative planning of new and that the existing transport infrastructure facilities are used in a balanced manner and their capacity is utilised. One of the mechanisms for the proposed implementation is the development of a transport cluster in the region.

5. The creation and development of the effective transport monitoring system (domestic and international) and freight and passenger traffic management in the Kaliningrad region using transport and logistics, digital and geo-information technologies.

\section{CONCLUSION}

The study has revealed the methodological shortcomings of modern transport models in terms of their application for analyses. First of all, there is no toolkit for the study and assessment of the transit function and transboundary effects. 
This hampers the identification of the development paths a regional transportation system, and its support measures. This is especially relevant for a territory where, due to its geographical location, transport and transit capabilities play a major role in the regional economy.

The analysis of freight turnover indicators in the Kaliningrad region revealed a high degree of influence of transit on the development of the region's transport system and its economy. Due to the relatively small size of Kaliningrad's economy, in different years, transit formed up to $20-30 \%$ of its total freight turnover in the region. The reduction in freight turnover after 2014 was caused not only by a decline in domestic production and consumption but also by a significant drop in the volume of transit goods. In this regard, the prospects for further transport system development and the growth of the regional economy are associated with changes in the volume of transit freight handled. The possible changes in the structure of transit consignments can also have a significant impact on it.

In order to study the effect of the transit function on the regional economy, the authors carried out a set of scenario calculations. There are three possible transit growth scenarios considered and compared with the baseline conditions. Under the first one, the growth results from an increase in the volume of intermediate goods and services. The second is the active inclusion of the region in global transport corridors. The third scenario involves the reduction in the share of raw materials and increased transportation of high-tech goods and containerised cargo. The scenario calculations have indicated a dependence of the added value on the transit trade in the Kaliningrad region. For example, the doubling of the transit volume creates an additional value added of $4-6 \%$, with the greatest growth achieved with the increase in the share of capital and consumer goods and services. If the Kaliningrad region' transit specialisation develops in the direction of increasing high-tech products and container cargo, the added value (GRP) in the region will be more than $20 \%$ higher compared to the baseline conditions, while targeting consumer goods and services will result in 14\% increase, and a preferential handling of raw materials and intermediate goods will result in an almost $10 \%$ growth.

The study results confirmed the assumption that the best option for the development of transit specialisation of the Kaliningrad region is to focus on capital and consumer goods and services. The implementation of this scenario requires the following support measures: an inclusion of the Kaliningrad region in international transport corridors; an inclusion of Kaliningrad transport organisations in the supply chains of Russian carriers of export and import goods; the consideration of the Kaliningrad issue in the framework of institutional and regulatory measures aimed to promote the integration of the Russian Federation into the international transport space; and the creation of appropriate institutional environment, the active use of transport and logistics, digital and geo-information technologies. 
The major limitations of the study included the need for additional verification and the evaluation of multiplicative effects formation in the regional economy related to the increase in cargo turnover due to transit traffic growth. This requires a series of specialised studies both in terms of the areas and types of economic activity and in certain categories of consignments. This data would significantly increase the reliability of the findings and would enable researchers to assess industry-specific effects. Despite the identified limitations, the proposed approach to the assessment of the transit function impact of the regional economy shall be recommended as a tool for measuring transboundary and transit effects to be used by other territories.

Further research may include a further study of the conditions for the increase of the transport sector's added value related to the changes in the volume and structure of transit cargo, the redistribution of added value and chains in favour of regional companies and organisations. The model available to the authors enables a further analysis of the process of the creation of added value in transit trade. This would enable researchers to determine what part of the added value remains in the region (since it is created by regional participants in the process of freight forwarding), and what part leaves the region (since it is created by Russian and international companies and organisations in the process of freight forwarding).

Acknowledgments. This research was performed at the Immanuel Kant Baltic Federal University with the financial support of the Russian Science Foundation (Project No. 18-17-00112 "Ensuring economic security of Russia's western border regions in the conditions of geopolitical turbulence") and the Russian Academic Excellence Project at the Immanuel Kant Baltic Federal University.

This research was funded by RFBR and Kaliningrad region according to the research project No. 19-45-393005 r_mol_a "Transport networks as a factor in the formation of a comfortable environment and the development of human capital in rural areas".

\section{REFERENCES}

ANOKHIN, A.A. and FEDOROV, G.M. (2018), 'O sootnoshenii protsessov polyarizatsii i vyravnivaniya urovnya sotsialno-ekonomicheskogo razvitiya subyektov Rossiyskoy Federatsii', Vestnik of St Petersburg University. Earth Sciences, 62, pp. 327-342. https://doi. org/10.21638/11701/spbu07.2017.401

BARROS, C.P. and PEYPOCH, N. (2009), ‘An evaluation of European airlines' operational performance', International Journal of Production Economics, 122, pp. 525-533. https://doi. org/10.1016/j.ijpe.2009.04.016 
BERNHOFEN, D.M., EL-SAHLI, Z. and KNELLER, R. (2016), 'Estimating the effects of the container revolution on world trade', Journal of International Economics, 98, pp. 36-50. https://doi. org/10.1016/j.jinteco.2015.09.001

BRoOKS, M.R. and CUlLINANE, K. (2007), Devolution, Port Governance and Port Performance, Research in Transportation Economics, JAI Press.

BULIS, A. and ŠKAPARS, R. (2013), 'Development of International Freight Transit in Latvia', Procedia - Social and Behavioral Sciences, 99, pp. 57-64. https://doi.org/10.1016/j.sbspro.2013.10.471

BUTTON, K.J. and HENSHER, D.A. (2005), Handbook of Transport Strategy, Policy and Institutions, Elsevier Oxford, UK.

CHEN, L. and NOTTEBOOM, T. (2014), 'A cost perspective on the location of value-added logistics services in supply chains', International Journal of Logistics Systems and Management (IJLSM), 18, pp. 24-48. https://doi.org/10.1504/ijlsm.2014.062121.

CHIU, Y.H., HUANG, C.W. and MA, C.M. (2011), 'Assessment of China transit and economic efficiencies in a modified value-chains DEA model', European Journal of Operational Research, 209, pp. 95-103. https://doi.org/10.1016/j.ejor.2010.05.010

CHOW, J.Y.J., YANG, C.H. and REGAN, A.C. (2010), 'State-of-the art of freight forecast modeling: Lessons learned and the road ahead', Transportation (Amst), 37, pp. 1011-1030. https://doi. org/10.1007/s11116-010-9281-1

DEMENTIEV, V.E., USTYUZHANINA, E.V. and EVSUKOV, S.G. (2018), 'Tsifrovaya transformatsiya tsepochek sozdaniya tsennosti: «ulybka» mozhet okazatsya «khmuroy»', Journal of Institutional Studies, 10, pp. 58-77. https://doi.org/10.17835/2076-6297.2018.10.4.058-077

DRUZHININA, G. and DONG,Y. (2018), 'One Belt - One Road Initiative: A Window of Opportunity for Russia's Western Border Regions', Baltic Region, 10, pp. 39-55. https://doi. org/10.5922/2079-8555-2018-2-3

GAREEV, T.R. and VOLOSHENKO, K.Yu. (2015), 'Osobennosti postroyeniya balansovoy modeli eksklavnogo regiona’, Econ. Reg, 2, pp. 113-124. https://doi.org/10.17059/2015-2-9

GUMENYUK, I. and MELNIK, D. (2013), 'The transnational territorial transport system of the Baltic Region', Baltic Region, 2, pp. 66-71. https://doi.org/10.5922/2079-8555-2012-1-8

HANSEN, P. and ANNOVAZZI-JAKAB, L. (2008), 'Facilitating Cross-Border Movement of Goods: A Sustainable Approach', The Global Enabling Trade Report, World Economic Forum, Geneva, Switzerland. pp. 67-76.

HAVENGA, J.H. (2018), 'Logistics and the future: The rise of macrologistics', Journal of Transport and Supply Chain Management, 12. https://doi.org/10.4102/jtscm.v12i0.336

HUMMELS, D.L. and SCHAUR, G. (2013), 'Time as a trade barrier', American Economic Review, 103, pp. 2935-2959. https://doi.org/10.1257/aer.103.7.2935

KHAN, A. and THOMAS, J.K. (2007), 'Inventories and the business cycle: An equilibrium analysis of (S, s) policies', American Economic Review, 97, pp. 1165-1188. https://doi.org/10.1257/ aer.97.4.1165

KUNAKA, C. and CARRUTHERS, R. (2014), Trade and Transport Corridor Management Toolkit, Washington, DC: World Bank. https://doi.org/10.1596/978-1-4648-0143-3

LAM, J.S.L. (2012), 'Benefits and barriers of supply chain integration: empirical analysis of liner shipping', International Journal of Shipping and Transport Logistics (IJSTL), 5, pp. 13-30. https://doi.org/10.1504/ijstl.2013.050553

LITVINENKO, M. and PALŠAITIS, R. (2006), 'The evaluation of transit transport probable effects on the development of countrys economy', Transport, 21, pp. 135-140. https://doi.org/ $10.3846 / 16484142.2006 .9638055$

MACHERET, D.A. and EPISHKIN, I.A. (2017), 'Mutual Influence of Institutional and Transport Factors of Economic Development: Retrospective Analysis', Journal of Institutional Studies, 9, pp. 80-100. https://doi.org/10.17835/2076-6297.2017.9.4.080-100 
MORRISON, A., RABELLOTTI, R. and PIETROBELLI, C. (2008), 'Global Value Chains and Technological Capabilities: A Framework to Study Industrial Innovation in Developing Countries', Oxford Development Studies, 36 (1). https://doi.org/10.4324/9780203937396.ch6

Protocol amending the Marrakesh agreement establishing The World Trade Organization, decision of 27 November 2014., https://docs.wto.org/dol2fe/Pages/SS/directdoc.aspx?filename=q:/ WT/L/940.pdf. [accessed on 23.12.2018].

RODRIGUE, J.P. (2012), 'Supply chain management, logistics changes and the concept of friction', [in:] Cities Regions and Flows. https://doi.org/10.4324/9780203106143

RODRIGUE, J.P. (2017), The Geography of Transport Systems, Fourth Edition, London.RUTNER, S.M. and LANGLEY, C.J. (2000), 'Logistics Value: Definition, Process and Measurement', International Journal of Logistics Management, 11. pp. 73-82. https://doi. org $/ 10.1108 / 09574090010806173$

TAVASSZY, L.A. (2006), 'Freight Modelling - An overview of international experiences', TRB Conf. Freight Demand Moddeling Tools Public Sect. Decis. Mak.

TAVASSZY, L.A. and de JONG, G. (2013), Modelling Freight Transport, Elsevier. https://doi. org/10.1016/C2012-0-06032-2

TSYBATOV, V.A. (2017), 'Problemy resursoobosnovannogo tselepolaganiya v zadachakh strategicheskogo planirovaniya regionalnogo razvitiya', Regional Economy. South of Russia, 1, pp. 67-76. https://doi.org/https://doi.org/10.15688/re.volsu.2017.1.7

VOLOSHENKO, K.Y and PONOMAREV, A.K. (2018), 'Introducing Sectoral Models into Regional Management: An Assessment of Regulatory Impacts on the Economy', Baltic Region, 9, pp. 72-86. https://doi.org/10.5922/2079-8555-2017-4-5

WANG, L., XUE, X., ZHAO, Z. and WANG, Z. (2018), 'The impacts of transportation infrastructure on sustainable development: Emerging trends and challenges', International Journal of Environmental Research and Public Health, 15, pp. 1172-1196. https://doi.org/10.3390/ ijerph15061172

YE, M., MENG, B. and WEI, S. (2012), Measuring Smile Curves in Global Value Chains, Institute of. Developing Economies. 